\title{
ANALISIS INTERPRETATIF POSTER FANMADE FILM "PARASITE" (2019)
}

\author{
Fahdel Muhammad $^{1)}$, Bayu Paksi Radithya Alfadjari' ${ }^{2)}$ \\ Program Studi Desain Komunikasi Visual, \\ Fakultas Bahasa dan Seni, Universitas Indraprasta PGRI \\ Jl. Nangka 58 C Tanjung Barat, Jakarta Selatan, 12530, Indonesia
}

fahdel.1997@gmail.com

\begin{abstract}
Abstrak
Industri perfilman saat ini cukup kompetitif, banyak rumah produksi berlomba-lomba membuat film yang dapat menarik perhatian banyak orang. Film "PARASITE" (2019) adalah film bergenre komedi tragis yang berkisahkan kesenjangan sosial dari sebuah keluarga miskin yang berusaha masuk ke dalam kehidupan keluarga yang kaya raya. Film ini menarik perhatian banyak orang karena dianggap memiliki makna-makna tersembunyi yang ada di dalamnya. Bentuk apresiasi yang dibuat karya oleh penggemar atas kekaguman dari sebuah film biasanya dalam bentuk gambar, poster, video dan musik, salah satunya poster fanmade film "PARASITE" (2019) karya Andrew Bannister. Analisis ini bertujuan untuk mengetahui makna-makna pada elemen poster fanmade film "PARASITE" (2019). Metode penelitian yang digunakan adalah dengan pendekatan kualitatif-deskriptif. Pengumumpulan data dilakukan dengan observasi. Teknik analisis yang digunakan adalah visual interpretatif. Dari hasil analisis mengenai makna tiap elemen poster fanmade film "PARASITE" (2019) terdapat semiotika pada tiap elemen yang ada di poster tersebut sesuai dengan apa yang ada di filmnya yang sarat akan makna.
\end{abstract}

Kata Kunci: Parasite, Interpretatif, Poster Film, Fanmade

\begin{abstract}
The film industry is currently quite competitive, many production houses are competing to make films that can attract the attention of many people. The film "PARASITE" (2019) is a tragic comedy genre film that tells the story of the social inequality of a poor family who tries to enter the life of a rich family. This film attracted the attention of many people because it was considered to have hidden meanings in it. The form of appreciation made by fans' admiration for a film is usually in the form of pictures, posters, videos and music, one of which is a poster fanmade of Andrew Bannister'sfilm "PARASITE" (2019). This analysis aims to determine the meanings of the poster elements for the fanmade film "PARASITE" (2019). The research method used is a qualitative-descriptive approach. Data collection was carried out by observation. The analysis technique used is visual interpretive. From the analysis of the meaning of each element of the poster fanmade film "PARASITE" (2019), there are semiotics in each element on the poster according to what is in the film which is full of meaning.
\end{abstract}

Keywords: Parasite, Interpretative, Movie Poster, Fanmade

Correspondence author: Fahdel Muhammad, fahdel.1997@gmail.com, Jakarta, and Indonesia 


\section{PENDAHULUAN}

Dunia perfilman menjadi salah satu industri hiburan yang sangat digemari oleh sebagian besar masyarakat, entah itu masyarakat yang tinggal di dalam negeri yaitu Indonesia atau masyarakat di luar negeri. Industri perfilman saat ini cukup kompetitif, banyak rumah produksi berlomba-lomba membuat film yang dapat menarik perhatian banyak orang.

Menurut Effendy (1989), film merupakan media yang bersifat visual dan audio visual untuk menyampaikan pesan kepada sekelompok orang yang berkumpul di suatu tempat. Banyak unsur yang dapat disajikan dalam film seperti keadaan, kebudayaan suatu daerah. Unsur-unsur tersebut dapat disajikan dengan memvisualisasikannya di dalam film. Kesuksesan sebuah film dapat dilihat melalui jumlah penonton dan penghargaan yang di raih oleh film tersebut.

Poster merupakan salah satu media promosi dari sebuah film. Poster merupakan suatu gambar yang mengombinasikan unsur-unsur visual seperti garis, gambar dan kata-kata yang bermaksud menarik perhatian serta mengkomunikasikan pesan secara singkat (Anitah, 2008). Poster film akan menampilkan pesan yang terdapat di film tersebut dengan mengemasnya secara menarik. Poster film dapat disajikan dengan berbagai gaya seperti ilustrasi, fotografi ataupun tipografi. Poster dibuat semenarik mungkin dengan konsep yang diperoleh dari hasil riset. Poster film digunakan untuk kepentingan komersial dan keberadaan poster hampir ada di seluruh judul film. Poster film memiliki makna yang dibentuk dengan sedemikian rupa melalui elemen-elemen visual. Beberapa film membuat poster untuk filmnya dengan menampilkan makna dari film tersebut secara jelas, tetapi terdapat juga beberapa film yang memilih untuk merahasiakan makna film-nya yang terdapat dari poster film itu sendiri. Makna yang dirahasiakan oleh pihak rumah produksi film tersebut merupakan salah satu strategi agar masyarakat yang melihat poster tersebut penasaran dan akhirnya membuatnya untuk menonton filmnya terlebih dahulu agar mengetahui makna dari film tersebut.

Pada tahun 2019, dunia perfilman digemparkan oleh sebuah film produksi asal Korea Selatan yang memperoleh banyak penghargaan. Film tersebut berjudul "PARASITE" (2019) yang digarap oleh sutradara yang bernama Bong Joon Ho. Film "PARASITE" (2019) adalah film bergenre komedi tragis, yang berkisahkan kesenjangan sosial dari sebuah keluarga miskin yang berusaha masuk ke dalam kehidupan keluarga yang kaya raya. Film ini menarik perhatian banyak orang karena dianggap memiliki makna-makna tersembunyi yang ada di dalamnya. Film yang sangat menarik maka akan mendapatkan bentuk apresiasi yang lebih, bentuk apresiasi tersebut dapat berupa penghargaan-penghargaan secara resmi. Namun, terdapat bentuk apresiasi yang unik untuk mengapresiasi suatu karya. Salah satunya adalah penggemar yang membuat karya seni berdasarkan film/karakter/cerita/musik/dan karya seni lainnya yang bersangkutan, sebagai bentuk kekaguman terhadap karya seni tersebut yang biasa disebut dengan fanmade. Bentuk apresiasi yang dibuat karya oleh penggemar atas kekaguman dari sebuah film biasanya dalam bentuk gambar, poster, video dan musik, dan dalam film "PARASITE" (2019) salah satu bentuk apresiasi oleh penggemarnya yaitu berupa poster fanmade film "PARASITE" (2019) karya Andrew Bannister yang penulis pilih karena menarik untuk dianalisis lebih dalam.

Berdasarkan identifikasi di atas, maka kemudian dirumuskan pertanyaan penelitian yaitu apa saja makna pada tiap elemen pada poster film tersebut? Sehingga analisis ini bertujuan untuk mengetahui makna-makna pada tiap elemen pada poster fanmade film "PARASITE" (2019).

\section{METODE PENELITIAN}

Metode penelitian yang digunakan dalam menganalisis poster fanmade film "PARASITE" (2019) yaitu dengan melakukan pendekatan secara kualitatif-deskriptif. Penelitian kualitatif menekankan pada pemahaman tentang masalah-masalah dalam kehidupan sosial berdasarkan realita pada kondisi penataan alami (natural setting). Dalam penelitian kualitatif, proses dan makna (perspektif subyek) lebih ditonjolkan. Pelaksanaan penelitian kualitatif pun bertolak dari data, memanfaatkan teori yang ada sebagai bahan penjelas, dan berakhir dengan suatu "teori" (Martono, 2016). Penelitian deskriptif adalah penelitian terhadap masalah-masalah berupa fakta-fakta saat ini dari suatu populasi yang meliputi kegiatan penilaian sikap atas pendapat terhadap individu, organisasi, keadaan ataupun prosedur yang ditujukan untuk 
mendeskripsikan suatu keadaan atau fenomena-fenomena apa adanya. Kedua metode di atas digunakan dalam penelitian ini untuk menganalisis poster fanmade film "PARASITE" (2019).

Pengumpulan data dengan cara melakukan observasi terhadap objek-objek yang terkait dengan film "PARASITE" (2019), yaitu seperti menyaksikan trailer video dari film "PARASITE" (2019), menyaksikan film "PARASITE" (2019), melakukan observasi terhadap akun media sosial instagram film "PARASITE" (2019), kemudian menyaksikan video-video review film "PARASITE" (2019) di Youtube, dan juga melengkapi data-data lainnya dengan studi literatur dari buku-buku yang terkait, kemudian menggunakan salah satu teknik dalam menganalisis data yaitu dengan teknik analisis visual interpretatif. Analisis visual interpretatif adalah analisis yang murni didasarkan dari teori-teori analisis visual, semiotika Peirce, dan analisis tingkatan makna melalui tanda-tanda atau simbol yang ada pada objek tersebut (Karnita \& Meiralarasari, 2010).

\section{HASIL DAN PEMBAHASAN}

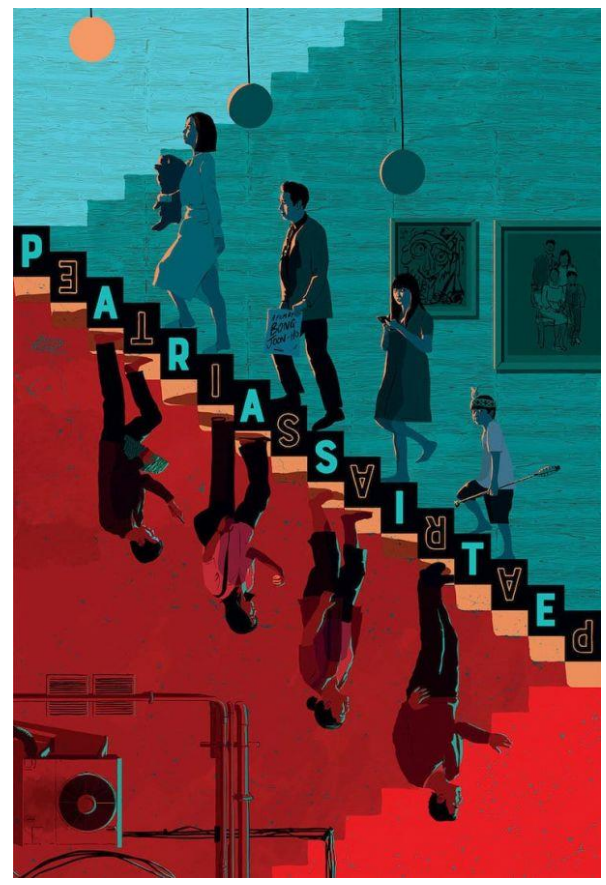

Gambar 1 Poster Fanmade Film "PARASITE" (2019) oleh Andrew Bannister Sumber: www.andrew-bannister.com

\section{Gambar}

Gambar yang ditampilkan oleh desainer poster fanmade dibuat dengan gaya ilustrasi. Ilustrasi adalah representasi visual dari sebuah naskah, baik itu konsep cerita dalam bentuk gagasan ide ataupun naskah tercetak untuk keperluan tertentu (Maharsi, 2016).

Dalam poster "PARASITE" (2019) versi fanmade ini, sang desainer berusaha menampilkan adegan yang terdapat dalam film "PARASITE". Adegan yang dicoba disajikan oleh desainer dengan ilustrasi tersebut adalah adegan menaiki tangga dan menuruni tangga. Dalam film ini adegan menaiki tangga dan menuruni tangga ditampilkan oleh sang sutradara dalam film dengan memvisualiasikan keluarga yang memiliki kekayaan atau kebutuhan yang selalu tercukupi ditampilkan dengan adegan yang selalu menaiki tangga untuk menuju ke dalam rumahnya, sedangkan keluarga yang kurang mampu ditampilkan oleh sutradara melalui adegan menuruni anak tangga yang banyak untuk menuju ke rumahnya.

Desainer dalam poster "PARASITE" (2019) versi fanmade ini memahami salah satu pesan yang terkandung dalam film "PARASITE", hal tersebut dapat terlihat dari apa yang 
divisualisasikan melalui karya poster ciptaannya. Dalam film "PARASITE" (2019), sang sutradara menampilkan kedua adegan tersebut dengan memvisualiasikan adegan menaiki tangga selalu didominasi dengan keluarga kaya dan adegan menuruni tangga didominasi dengan adegan yang dilakukan oleh keluarga kurang mampu. Dua hal tersebut dapat menyimbolkan bahwa dalam film "PARASITE" (2019) terdapat ketimpangan sosial sangat jelas adanya dan nyata.

Adegan menaiki tangga dan menuruni tangga tersebut menjadi sebuah realita kehidupan yang dilebih-lebihkan dan disajikan melalui unsur dalam sebuah film, yaitu durasi dari dua adegan tersebut. Sehingga tangga dalam film ini menjadi sebuah hal yang menandai ketimpangan kelas status sosial yang ditampilkan melalui garis vertikal adalah sesuatu yang khas. "Atas" dan "bawah" dalam film "PARASITE" tersebut ada dalam dunia yang sifatnya dekat dengan keseharian. Sehingga dalam dua adegan tersebut sutradara ingin memberikan audiens sebuah stereotip bahwa perbedaan kondisi realitas sosial yang terjadi antara kaya dan miskin itu jauh, yang kaya akan semakin ke atas atau semakin kaya dan yang miskin akan terus miskin.

Selain itu, ketimpangan sosial yang jelas dihadirkan oleh desainer yang membuat poster "PARASITE" (2019) versi fanmade ini menampilkan ilustrasi kondisi sekitar lingkungan dalam keluarga tersebut, dapat dilihat keluarga yang kaya berada dalam lingkungan yang menggambarkan keluarga tersebut berada dalam rumah dengan lukisan serta pajangan yang terdapat di dinding rumahnya, sementara keluarga yang kurang mampu diilustrasikan dengan lingkungan yang menggambarkan lingkungan diluar rumah dengan adanya kipas $A C$.

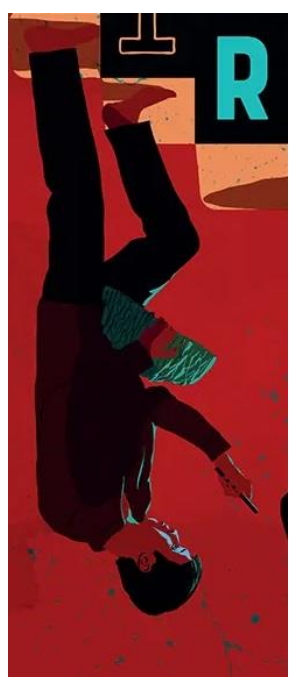

Gambar 2 Batu yang dipegang oleh Ki-Woo pada poster fanmade Sumber: www.andrew-bannister.com

Selain isu ketimpangan sosial yang ditampilkan oleh sang desainer pencipta karya poster "PARASITE" (2019) versi fanmade, dalam poster ini sang desainer juga menampilkan unsur dalam film yang cukup membuat penasaran yaitu batu yang disertai didalam film. Batu tersebut merupakan batu Cendekia atau Philosopher's Stone, yang di awal film batu tersebut diberikan oleh temannya Ki-Woo (anak laki-laki keluarga miskin) saat menawarkan bantuan pekerjaan menjadi guru les bahasa Inggris di rumah keluarga kaya. Batu tersebut adalah sebuah metafora atau sebuah permisalan sebuah bantuan dana atau hutang berikut dengan suku bunganya. Dalam sistem ekonomi kapitalis, hutang dipromosikan sebagai sebuah solusi dan di dalam film tersebut dikatakan bahwa batu tersebut akan mendatangkan kemakmuran. Dalam dialog lain, Ki-Woo mengatakan bahwa batu ini sudah melekat padanya, yang hal tersebut diasosiasikan dengan tenor, jangka waktu kredit atau lamanya angsuran kredit berlangsung. Batu tersebut memang memberikan kemakmuran yang singkat pada keluarga miskin tersebut, ketika semua anggota keluarganya telah berhasil mendapatkan pekerjaan di rumah keluarga kaya. 
Akan tetapi, semua hal pekerjaan tersebut hanya berlangsung sementara, saat semua permasalahan muncul satu per satu menimpa keluarga miskin yang diasosiasikan sebagai suku bunga yang mencekik, membuat keluarga miskin harus turun ke tempat tinggal mereka yang semula yang kemudian menyadari bahwa rumah mereka terendam oleh banjir sehingga mereka kehilangan semua barang berharga yang mereka miliki yang ada di rumah kecuali satu hal yaitu batu cendekia atau hutang yang selalu melekat pada diri mereka walaupun dalam keadaan apapun sehingga adegan yang menyertai batu cendekia yang ada pada film "PARASITE" (2019) menjadi sebuah realita yang dilebih-lebihkan dari kehidupan ketika sebuah keluarga berhutang yang hal tersebut bertujuan untuk memeras emosi audiens dengan ideologi yang ingin disampaikan oleh sutrada film "PARASITE" (2019) kepada audiens dengan batu cendekia tersebut sebagai hal yang menandai bahwa yang kaya akan tetap kaya, yang miskin akan menderita karena hutang yang terus mencekik mereka karena kebutuhan hidup yang mereka butuhkan. Pengaruh adegan yang menyertai batu tersebut adalah dapat membangun/menggiring audiens untuk percaya bahwa berhutang/pinjaman dana adalah lingkaran setan yang tidak akan ada habisnya.

\section{Tipografi}

Dengan adanya perkembangan zaman, tipografi digunakan untuk keperluan dalam sebuah desain. Tipografi adalah seni tentang mendesain, mencipta, memilih dan memilah, menata dan mengorganisir huruf dalam segala aspek ketentuan yang meliputi dirinya dan berkaitan erat dengan estetika serta komunikasi yang efektif karena mampu mewakili konsep dan inti pesan yang disampaikan melalui karakter serta ciri khas huruf yang dimilikinya (Maharsi, 2013). Tipografi dalam desain memiliki unsur yang berkait dengan bidang keimuan lainnya seperti komunikasi, teknologi, psikologi dan lainnya. Dalam tipografi, salah satunya terdiri dari typeface. Istilah typeface lebih mengarah pada bentuk desain (Rustan, 2013). Kehadiran tipografi di dalam dunia desain sangat membantu para desainer agar dapat menyampaikan pesan ataupun informasi kepada masyarakat luas melalui karya desainnya.

Dalam pembahasan kali ini, kami ingin membahas tipografi yang diterapkan pada poster "PARASITE" (2019) versi fanmade. Typeface yang digunakan penggemar dalam membuat poster "PARASITE" (2019) adalah typeface yang memiliki jenis sans serif. Terdapat dua kata yang sama yaitu "PARASITE" yang ditampilkan dalam poster tersebut, dua kata tersebut ditampilkan berlawanan, baik dalam arah serta gaya atau karakter.

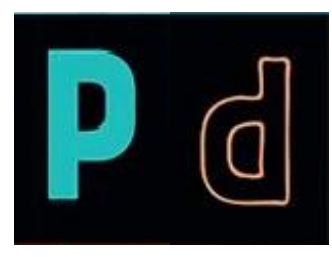

Gambar 3 Huruf "P" sebagai perwakilan kata "PARASITE" (2019) pada poster fanmade Sumber: www.andrew-bannister.com

Berdasarkan hasil analisis setelah menonton film "PARASITE" (2019) serta mendalami data-data lain yang bersangkutan dengan film tersebut, kata "PARASITE" dengan font color yang memiliki fill atau isi yang berwarna biru yang diletakkan di bagian tangga atas oleh desainer. Desainer tersebut ingin menyampaikan bahwa keluarga yang berada di tangga bagian atas adalah keluarga yang memiliki keadaan serba terpenuhi atau dapat dikatakan dengan kaya raya yang hal tersebut sama dengan makna warna biru yaitu ketenangan. Selanjutnya, kata "PARASITE" pada bagian bawah tangga yang tidak disertai dengan fill pada masing-masing hurufnya serta hanya menampilkan outline saja berwarna merah, dapat dikatakan bahwa desainer ingin menyampaikan bahwa hal tersebut mewakilkan keadaan keluarga yang berada di bagian bawah tangga pada 
poster tersebut berada pada posisi keluarga yang kebutuhannya tidak selalu tercukupi yang hal tersebut sama dengan makna warna merah yaitu nafsu dan hasrat.

\section{Warna}

Dalam kehidupan sehari-hari, warna sering digunakan untuk menarik perhatian misalnya di dalam dunia perdagangan, periklanan digunakan kombinasi warna agar suatu produk menjadi menarik. Lampu pengatur lalu lintas juga menggunakan warna. Militer menggunakan kombinasi warna agar dapat mengaburkan penglihatan musuh. Bahkan warna dan kombinasinya dapat mempengaruhi situasi seperti menimbulkan rasa tenang, membangkitkan suasana gembira, murung, sedih dan marah. Manusia menggunakan warna pakaian agar dapat menarik perhatian, bahkan kombinasi warna yang digunakan untuk merias wajah yang sering digunakan perempuan dimaksudkan agar kelihatan tambah cantik dan menarik (Adisendjaja, 2003).

Warna merupakan sebuah subjek yang menjadi salah satu hal yang terpenting dalam mempengaruhi daya tarik sebuah benda atau karya atau desain. Warna memberikan vibrasi tertentu di dalam sebuah desain. Sebagai desainer, harus mempertimbangkan dari segi pewarnaan dalam membuat suatu karya, karena warna menambah keefektifan penyampaian pesan yang klien inginkan untuk dikomunikasikan kepada audience. Warna yang digunakan mencakup tone dan maknanya yang sangat mempengaruhi penilaian dan reaksi audience. Warna lebih dari sekedar hiasan semata dalam sebuah desain, tetapi lebih kepada bahasa emosional dan simbolik. Warna tidak boleh sekedar menjadi suatu tambahan dalam desain tetapi harus disesuaikan juga dengan keseluruhan makna desain tersebut. Persepsi terhadap sebuah warna memang tidak akan sama antara satu orang dengan yang lainnya, apalagi karena pengaruh suatu kebudayaan pada negara tertentu (Monica \& Luzar, 2011).

Berikutnya adalah mengenai warna, menurut hasil dari analisis mengenai warna secara keseluruhan yang digunakan dalam poster adalah warna merah dan warna biru (warna panas dan warna dingin).

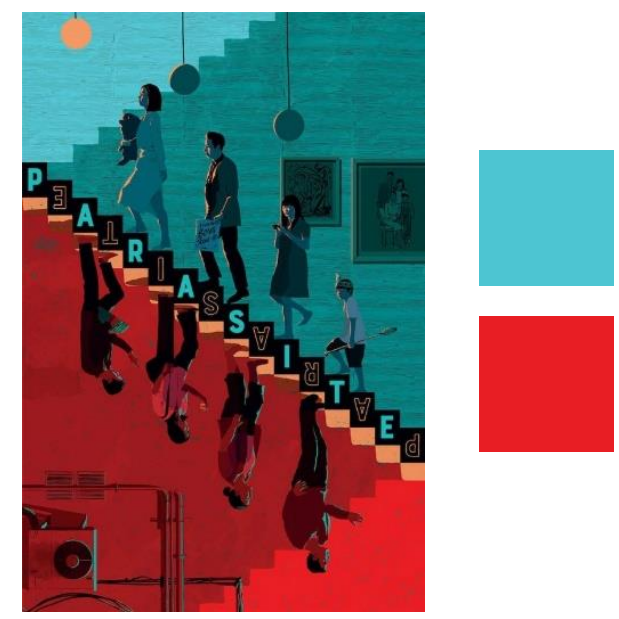

Gambar 4 Warna yang digunakan pada poster fanmade film "PARASITE" (2019)

Sumber: www.andrew-bannister.com

Menurut Basuki (2013), penggunaan warna merah dalam desain sering dihubungkan dengan bahaya, hasrat dan warna yang mempunyai unsur emosional yang kuat. Sementara warna biru menurut Monica \& Luzar (2011) adalah warna yang dihubungkan dengan depresi, kelesuan dan dingin. Dan menurut Lebond (2017), warna merah memiliki sifat negatif yaitu nafsu, emosi, penuntut dan dominasi, sedangkan warna biru memiliki sifat negatif yaitu dingin, bangga diri, kurang empati dan tak ramah.

Oleh karena itu, dapat ditarik kesimpulan sesuai data-data dari film yang sudah ditonton dan data lainnya yang kemudian mencocokkannya dengan makna-makna warna di atas bahwa dalam poster tersebut penggunaan warna biru dan merah selain menunjukkan sebuah kontras 
antara warna panas dan dingin yang menyimbolkan keluarga kaya dan keluarga miskin, juga bermaknakan bahwa sang desainer ingin menunjukkan bahwa 2 keluarga tersebut memiliki sifat yang disimbolkan dengan warna yang digunakan.

Penggunaan warna biru pada poster tersebut menyimbolkan bahwa keluarga kaya tersebut memiliki sifat yang dingin, kurang empati dan kurang ramahnya terhadap keluarga yang miskin, yang mana hal tersebut ditunjukkan pada salah satu scene saat keluarga yang kaya mencium aroma kurang mengenakan dari salah satu anggota keluarga miskin sehingga ia menutup hidungnya yang mana tindakan tersebut adalah tindakan yang kurang berempati dan kurang ramah yang dapat menyinggung perasaan. Sehingga hal tersebut mendukung makna dari penggunaan warna biru pada poster film fanmade tersebut.

Penggunaan warna merah pada poster tersebut menyimbolkan bahwa keluarga yang miskin tersebut memiliki sifat yang memiliki hasrat, berbahaya dan nafsu atas kekayaan sementara yang didapatkan, yang mana hal tersebut ditunjukkan dari awal film yang menunjukkan keluarga miskin tersebut yang menipu keluarga kaya untuk bisa bekerja di rumahnya, dan juga di akhir film keluarga miskin tersebut membuat kekacauan yang berbahaya di rumah keluarga kaya walaupun hal tersebut memiliki alasan kuat yang membuat keluarga miskin tersebut melakukan kekacauan.

\section{Tata Letak}

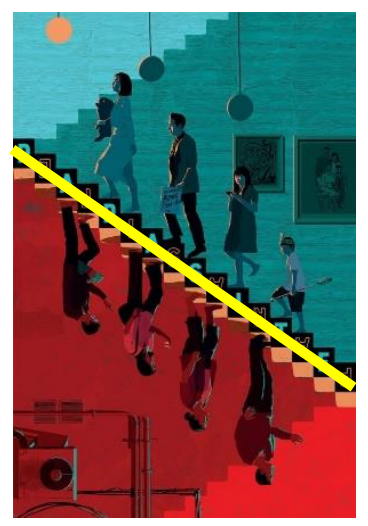

Gambar 5 Garis diagonal yang membagi 2 poster yang membentuk keseimbangan simetris Sumber: www.andrew-bannister.com

Untuk selanjutnya kami akan membahas mengenai tata letak pada poster film ini. Layout adalah tata letak elemen-elemen desain terhadap suatu bidang dalam media tertentu untuk mendukung konsep atau pesan yang dibawanya (Rustan, 2008).

Tata letak pada poster film ini menerapkan layout dengan keseimbangan yang simetris, keseimbangan simetris atau keseimbangan formal terjadi ketika sebuah komposisi memiliki elemen yang sama dengan salah satu sisi pada sebuah garis sumbu (Kuswanto, 2017). Yang terlihat jika poster ditarik garis lurus di tengah dan dibagi menjadi dua, maka akan terlihat persamaan, terbagi rata, dan seimbang. Hal tersebut terlihat pada tangga yang membagi dua poster tersebut menjadi bagian atas dan bagian bawah, atas untuk keluarga yang kaya dan bawah untuk keluarga yang miskin dan di tangga tersebut terdapat judul film yang memisahkan antar dua keluarga tersebut.

Makna penggunaan tata letak yang simetris menurut hasil analisis kami setelah menonton filmnya dan mendalami data-data yang ada bahwa poster tersebut menunjukkan dan menekankan konflik yang ada di film tersebut dari dua hal yang kontras, atas dan bawah, biru dan merah, kaya dan miskin yang hal tersebut sudah menjadi pemahaman secara umum dari keseimbangan simetris. Kemudian posisi keluarga yang miskin yang mencoba menaiki tangga seperti melambangkan ingin untuk menuju menjadi kaya dan posisi keluarga yang kaya yang menaiki tangga rumahnya di rumah mewahnya dan akan terus menjadi kaya. 


\section{SIMPULAN}

Dari hasil analisis dalam pembahasan mengenai makna yang terdapat pada tiap elemen poster fanmade film "PARASITE" (2019) terdapat kesesuaian dengan apa yang ada di filmnya tersebut. Sang desainer memahami salah satu pesan yang terkandung dalam film "PARASITE" (2019), hal tersebut dapat terlihat dari apa yang divisualisasikan melalui karya poster ciptaannya. Pesan yang terkandung dalam film tersebut terdapat pada adegan menaiki dan menuruni tangga. Hal tersebut dalam film "PARASITE" (2019) menampilkan pesan akan adanya ketimpangan sosial. Sehingga tangga dalam film ini menjadi sebuah hal yang menandai ketimpangan kelas status sosial yang ditampilkan melalui garis vertikal. "Atas" dan "bawah" dalam film "PARASITE" tersebut ada dalam dunia yang sifatnya dekat dengan keseharian. Sehingga dalam dua adegan tersebut sutradara ingin memberikan audiens sebuah stereotip bahwa perbedaan kondisi realitas sosial yang terjadi antara kaya dan miskin itu jauh, yang kaya akan semakin ke atas atau semakin kaya dan yang miskin akan terus miskin. Dalam poster ini sang desainer menampilkan batu cendekia, dimana batu tersebut adalah sebuah permisalan dari sebuah bantuan dana atau hutang berikut dengan suku bunganya. Adegan yang menyertai batu cendekia yang ada pada film "PARASITE" (2019) memiliki ideologi yang ingin disampaikan oleh sutradara kepada audiens dengan batu cendekia tersebut sebagai hal yang menandai bahwa yang kaya akan tetap kaya, yang miskin akan menderita karena hutang yang terus mencekik mereka karena kebutuhan hidup yang mereka butuhkan. Pengaruh adegan yang menyertai batu tersebut dapat membangun atau menggiring audiens untuk percaya bahwa berhutang atau pinjaman dana adalah lingkaran setan yang tidak akan ada habisnya. Kata "PARASITE" dengan font color yang memiliki fill berwarna biru bermakna bahwa keluarga yang berada di tangga bagian atas adalah keluarga yang memiliki keadaan serba terpenuhi atau dapat dikatakan dengan kaya raya yang hal tersebut sama dengan makna warna biru yaitu ketenangan. Kata "PARASITE" pada bagian bawah tangga yang tidak di-fill dan hanya menampilkan outline berwarna merah mewakilkan keadaan keluarga yang berada dibagian bawah tangga pada poster tersebut berada pada posisi keluarga yang kebutuhannya tidak selalu tercukupi yang hal tersebut sama dengan makna warna merah yaitu nafsu dan hasrat. Penggunaan warna biru pada poster tersebut menyimbolkan bahwa keluarga kaya tersebut memiliki sifat yang dingin, kurang empati dan kurang ramahnya terhadap keluarga yang miskin, dan penggunaan warna merah pada poster tersebut menyimbolkan bahwa keluarga yang miskin tersebut memiliki sifat yang memiliki hasrat, berbahaya dan nafsu atas kekayaan sementara yang didapatkan. Tata letak pada poster film ini menerapkan layout dengan keseimbangan yang simetris, poster tersebut menunjukkan dan menekankan konflik yang ada di film tersebut dari dua hal yang kontras, atas dan bawah, biru dan merah, kaya dan miskin yang hal tersebut sudah menjadi pemahaman secara umum dari keseimbangan simetris. Kemudian posisi keluarga yang miskin yang mencoba menaiki tangga seperti melambangkan ingin untuk menuju menjadi kaya dan posisi keluarga yang kaya yang menaiki tangga rumahnya di rumah mewahnya dan akan terus menjadi kaya.

\section{DAFTAR PUSTAKA}

Adisendjaja, Y. H. (2003). Warna dan maknanya dalam kehidupan. Makalah disajikan pada Seminar Sehari Bersama Alam II oleh BEM FPMIPA Universitas Pendidikan Indonesia, Bandung (Vol. 24).

Anitah, S. (2008). Media pembelajaran. Surakarta: UNS Press.

Basuki, A. (2013). Makna warna dalam desain. Surabaya: Politeknik.

Effendy, O. U. (1989). Kamus komunikasi. Bandung: Bandar Maju. 
Karnita, R., \& Meiralarasari, D. (2010). Metode visual interpretatif terhadap tampilan visual iklan media cetak sebagai alternatif analisis dari metode eye tracking. J@TI Undip: Jurnal Teknik Industri, 5(1), 33-40.

Kuswanto, H. (2017). Analisis prinsip layout and composition pada web design perusahaan PT. Bank Rakyat Indonesia, Tbk dan PT. FIF Group berdasarkan buku "The Principle of Beautifull Website Design by Jason Beaird". Elinvo (Electronics, Informatics, and Vocational Education), 2(1), 1-7.

Lebond, B. (2017). Arti dan pengaruh warna bagi psikologi manusia. Warna dapat mempengaruhi mood. Retrieved from psyline. id: https://psyline. id/arti-dan-pengaruh-warnabagipsikologi-manusia.

Maharsi, I. (2013). Tipografi - Tiap font memiliki nyawa dan arti. Yogyakarta: CAPS (Center for Academic Publishing Service).

Maharsi, I. (2016). Ilustrasi. Yogyakarta: Badan Penerbit ISI.

Martono, N. (2016). Metode penelitian kuantitatif: Analisis isi dan analisis data sekunder. Edisi Revisi 2. Depok: PT Rajagrafindo Persada.

Monica, M., \& Luzar, L. C. (2011). Efek Warna dalam Dunia Desain dan Periklanan. Humaniora, 2(2), 1084-1096.

Rustan, S. (2008). Layout dasar \& penerapannya. Jakarta: PT Gramedia Pustaka Utama.

Rustan, S. (2013). Font and tipografi. Jakarta: Gramedia Pustaka Utama 